\title{
KONSELING KARIR KELOMPOK COGNITIVE INFORMATION PROCESSING UNTUK MENINGKATKAN PENGAMBILAN KEPUTUSAN KARIR SISWA
}

\author{
Resi Gusti Nurrega ${ }^{1}$, Hepi Wahyuningsih, Uly Gusniarti \\ Fakultas Psikologi dan IImu Sosial Budaya, Universitas Islam Indonesia \\ resigusti@gmail.com
}

\begin{abstract}
ABSTRAK
Penelitian ini bertujuan untuk menguji pengaruh konseling karir kelompok cognitive information processing untuk meningkatkan kemampuan pengambilan keputusan karir siswa. Penelitian ini menggunakan desain Pretest-Posttest Control Group Design. Partisipan dalam penelitian ini adalah 16 orang siswa kelas XI di SMAN "X" Yogyakarta yang berjenis kelamin perempuan dan laki-laki, berusia 17 tahun dan dibagi dalam dua kelompok. Setelah dilakukan proses random, maka terpilih satu kelompok $(\mathrm{n}=8)$ sebagai kelompok eksperimen dari SMAN " $\mathrm{X}$ " yang menerima perlakuan berupa konseling karir kelompok CIP. Satu kelompok lainnya $(n=8)$ sebagai kelompok kontrol. Skala career thought inventory yang dibuat sendiri oleh peneliti yang dipergunakan sebagai alat ukur. Uji hipotesis menggunakan analisis non-parametrik berupa Mann Whitney $U$ Test untuk menguji perbedaan nilai berdasarkan kelompok, yaitu eksperimen dan kontrol. Hasil pengujian menunjukkan bahwa konseling karir kelompok berpengaruh dalam meningkatkan kemampuan pengambilan keputusan karir siswa $(Z=-3,313, p=$ $0,000$, dimana $p<0,05)$.
\end{abstract}

Kata kunci: Pengambilan keputusan karir, Cognitive Information Processing, Konseling karir.

\section{COGNITIVE INFORMATION PROCESSING'S GROUP CAREER COUNSELING TO INCREASE CAREER DECISION MAKING SKILL OF STUDENTS}

\begin{abstract}
The study examined the influence of cognitive information processing's group career counseling to increase career decision making skill of students. This study uses pretest-posttest control group designs. The participants were 16 senior high school students from SMAN "X" Yogyakarta. They were men and women aged 17 years old, and classified into two groups. One group $(n=8)$ received cognitive information processing's group career counseling as experimental group and the other $(n=8)$ as controlled group. Participants were ass using career thought inventory that created by researchers based on career thought inventory's concept of Peterson. The results of hypothesis test using non-parametric analyzes such as Mann Whitney $U$ Test to examine the difference in value based on the group, namely the experimental and control. This suggests that there are significant differences in the implementation of post-test between the experimental and control group. By using mann whitney, the result concluded that cognitive information processing's group career counseling was significantly affecting the increase career decision making skill of students $(Z=-3,313, p=0,000$, where $p<0,05)$.
\end{abstract}

Keywords: Career Decision Making, Cognitive Information Processing, Career Counseling. 


\section{Journal of Psychological Science and Profesion (JPSP)}

Vol.2, No.1, April 2018

E-mail: jurnal.psp@unpad.ac.id

\section{PENDAHULUAN}

Perkembangan karir pada masa remaja disebut tahap pertumbuhan, pada usia 14 sampai 15 tahun dan tahap eksplorasi, pada usia 16 sampai 19 tahun (Super dalam Sharf, 2006). Selama tahun-tahun SMA, siswa membuat keputusan karir penting (misalnya, menyelesaikan SMA, mencari pekerjaan vs mengejar pendidikan lebih lanjut) yang akan pasti mempengaruhi aspirasi karir mereka, rencana, dan tujuan (McWhirter, Rasheed, \& Crothers dalam Gushue, 2006). Taveira (Witko, 2005) mengatakan bahwa proses eksplorasi karir dan pengambilan keputusan dapat menjadi waktu yang sangat menegangkan dalam kehidupan remaja. Dalam reaksi terhadap stres ini, remaja mungkin mencoba untuk menempatkan tanggung jawab untuk membuat keputusan karir ke orang lain dan bahkan mungkin menunda atau menghindari membuat pilihan, yang pada akhirnya dapat menyebabkan pengambilan keputusan yang optimal (Gati \& Saka dalam Germeijs dan Verchueren, 2006).

Sebagian besar dari Siswa SMA belum mampu untuk memilih dan memutuskan arah pilihan karir ke depan disebabkan oleh kurangnya pengetahuan tentang jurusan atau program studi yang akan dipilih ketika lulus SMA nanti, serta pekerjaan yang cocok dan sesuai dengan bakat dan kemampuannya (Fasha, dkk, 2015). Hal tersebut sejalan kondisi di SMAN "X" Yogyakarta bahwa mayoritas siswa kelas XI sampai saat ini masih bingung terhadap minat serta bakat yang mereka miliki. Sehingga mereka belum memiliki gambaran yang jelas mengenai kesesuaian karir. Sedangkan untuk siswa kelas XII masih banyak yang mengalami kesulitan dalam memilih jurusan kuliah hingga waktu menjelang ujian nasional.

Berdasarkan wawancara yang diperoleh dari guru BK SMAN "X" Yogyakarta, didapatkan data bahwa selama ini guru belum memberikan bimbingan karir secara maksimal kepada para siswa. Pemberian informasi terkait karir hanya diberikan di dalam kelas kepada seluruh siswa. Para guru tidak menyediakan layanan khusus yang berhubungan dengan karir, baik dalam bentuk konseling individual maupun kelompok. Hal tersebut di latarbelakangi oleh minimnya jam yang diberikan kepada guru BK untuk masuk ke kelas. Selain melakukan wawancara dengan guru serta beberapa siswa di kelas XI dan kelas XII, peneliti juga melakukan survei melalui blanko kepada 94 siswa kelas XI.

Hasil dari survei tersebut dapat dilihat pada tabel di bawah ini:
Tabel 1. Hasil Survei di SMAN "X" Yogyakarta

$\mathrm{N} \quad$ Prosentase

\begin{tabular}{ccc}
\hline $\begin{array}{c}\text { Bimbingan karir } \\
\text { yang dilakukan } \\
\text { oleh sekolah }\end{array}$ & $\begin{array}{c}\text { Sudah Cukup } \\
31 \text { siswa } \\
\text { Belum Cukup } \\
\text { Jumlah siswa }\end{array}$ & $33 \%$ \\
& 94 siswa & $100 \%$ \\
Informasi karir & $\begin{array}{c}\text { Sudah Cukup } \\
11 \text { siswa }\end{array}$ & $11,71 \%$ \\
yang dimiliki & $\begin{array}{c}\text { Belum cukup } \\
83 \text { siswa }\end{array}$ & $88,29 \%$ \\
Jumlah & 94 siswa & $100 \%$ \\
\hline
\end{tabular}

Berdasarkan tabel di atas dapat disimpulkan bahwa sebanyak $67 \%$ dari 94 siswa kelas XI merasa bimbingan karir yang diberikan oleh sekolah belum cukup. Sedangkan 33\% lainnya merasa sudah cukup. Selain itu, sebanyak 88,29\% dari 94 siswa kelas XI merasa kekurangan informasi karir. Sedangkan, 11,71\% lainnya merasa telah memiliki informasi karir yang cukup. Menurut Gati dan Saka (Germeijs dan Verchueren, 2006) bahwa fenomena yang peneliti sampaikan diatas merupakan salah satu bentuk ketidakmampuan dalam mengambil keputusan.

Blum dan Balinsky (1970) berpendapat bahwa terdapat tiga metode bimbingan karir, yaitu tes psikologi, konseling, dan pelatihan. Intervensi dalam proses perkembangan karir yang sangat efektif untuk membantu dalam mengarahkan karir pada anak dan remaja, antara lain konseling karir individu, konseling karir kelompok, kurikulum karir berbasis kelas, dan pendidikan karir (Brown dan Lent, 2005). Brown dan Lent (2005) menyatakan bahwa salah satu intervensi yang tepat untuk diberikan pada usia remaja adalah konseling karir kelompok. Menurut Herr, Cramer dan Niles (Sharf, 2006) tujuan dari konseling kelompok karir adalah membantu klien dalam mengeksplorasi tentang kejuruan dan membuat keputusan karir. Myrick (1993) percaya bahwa menggunakan konseling kelompok dengan siswa SMA adalah layanan yang sangat baik yang dapat disediakan oleh konselor. Pengakuan bahwa rekan-rekan mereka menghadapi masalah yang sama dan ketidakpastian dapat membantu siswa memperoleh perspektif yang berbeda tentang kekhawatiran mereka sendiri, dan dapat mendorong lebih kemandirian dan inisiatif pada bagian mereka dalam mencari informasi yang akhirnya dapat menyebabkan untuk lebih sukses dalam pengambilan keputusan mereka (Isaacson \& Brown dalam Giallombardo, 2005).

Peneliti memilih untuk memberikan intervensi dalam bentuk konseling kelompok menggunakan pendekatan cognitive information 
Vol.2, No.1, April 2018

E-mail: jurnal.psp@unpad.ac.id

processing untuk siswa kelas XI SMA. CIP mendalilkan bahwa pengambilan keputusan karir yang efektif hanya dapat terjadi bila kognisi disfungsional juga dibahas (Sampson, dkk dalam Mcclair, 2010). Hasil penelitian disertasi yang dilakukan oleh Perry (2012) membuktikan bahwa dampak dari intervensi kelompok karir menggunakan cognitive information processing (CIP) mampu meningkatkan kemampuan pengambilan keputusan karir dan pemecahan masalah pada mahasiswa. Selain itu, hasil penelitian dari Lenz, dkk (2009) menggambarkan bahwa konseling karir menggunakan teori cognitive information processing (CIP) dapat menuntun keputusan tentang mengintegrasikan karir dan kesehatan mental.

\section{Pengambilan Keputusan Karir}

Pengambilan keputusan merupakan pengubahan pilihan menjadi langkah-langkah tindakan tertentu (Sampson, dkk dalam Perry, 2012). Brown \& Brooks (Rowland, 2004) mendefinisikan pengambilan keputusan karir sebagai sebuah proses pemikiran seseorang dalam mengintegrasikan atau menggabungkan pengetahuan tentang dirinya dengan pengetahuan suatu pekerjaan untuk membuat pilihan berkaitan dengan karir. Pengambilan keputusan karir adalah proses yang kompleks dan beberapa remaja mungkin mengalami kesulitan yang mencegah mereka dari membuat keputusan karir atau kurang optimal dalam membuat keputusan (Gati dan Saka dalam Germeijs dan Verchueren, 2006).

\section{Karakteristik Pengambilan Keputusan Karir}

Peterson, Sampson, dan Reardon (Sharf, 2006) mengungkapkan karakteristik dari pengambilan keputusan karir yang baik dan dikenal dengan akronim CASVE cycle (comunication, analysis, synthesis, valuing, dan execution).

\section{Communication (Komunikasi)}

Proses komunikasi dimulai ketika individu mendapatkan input dalam diri mereka sendiri atau dari lingkungan. Individu menyadari bahwa mereka perlu membuat keputusan karir melalui pikiran dan perasaan mereka sendiri (internal) serta melalui peristiwa komunikasi dari orang lain dalam kehidupan mereka (ekstrenal) (Patton dan McMahon, 2001).

2. Analysis (Analisis)

Proses analisis adalah ketika individu mencoba untuk mengumpulkan dan memahami semua informasi yang relevan terkait dengan pilihan mereka (Patton dan McMahon, 2001). Individu memerika kembali nilai-nilai, minat, keterampilan, dan situasi keluarga.

3. Synthesis (Sintesis)

Individu melakukan kegiatan yang membantu mereka mempersempit pilihan mereka. Pada proses ini individu mempertimbangkan banyak solusi yang memungkinkan.

4. Valuing (Penilaian)

Individu mempertimbangkan tiga sampai lima pilihan yang telah dihasilkan dan dipertimbangkan kelebihan serta kekurangan masing-masing. Dalam proses ini, individu membuat urutan pilihan tentatif pertama, kedua maupun pilihan ketiga sebagai cadangan.

5. Execution (Eksekusi)

Pada fase ini, individu merumuskan dan berkomitmen untuk membuat rencana aksi untuk menerapkan pilihan tentatif mereka.

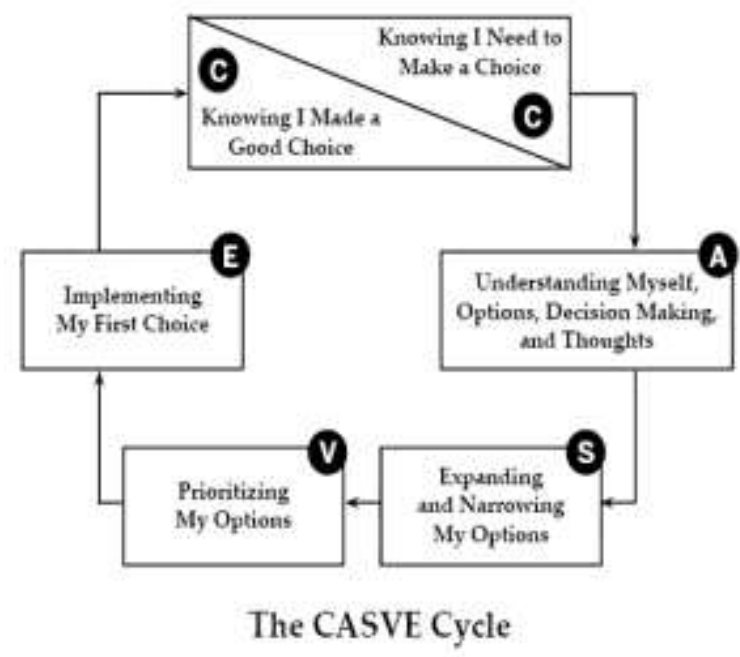

Gambar 1. A guide to good decision making

\section{Faktor-Faktor Yang Mempengaruhi Pengambilan Keputusan Karir}

Winkel dan Hastuti (2006) menjelaskan mengenai faktor yang mempengaruhi pengambilan keputusan karir seseorang, yaitu faktor internal yang mencakup nilai-nilai kehidupan, taraf Inteligensi, bakat khusus, minat, sifat-sifat, pengetahuan, keadaan jasmani dan faktor eksternal yang mencakup masyarakat, keadaan sosial ekonomi negara atau daerah, SES keluarga, seluruh anggota keluarga besar maupun keluarga inti, pendidikan sekolah, pergaulan dengan teman sebaya, dan untutan yang melekat pada masing-masing jabatan atau program studi. 
Vol.2, No.1, April 2018

E-mail: jurnal.psp@unpad.ac.id

\section{Konseling Karir Kelompok Cognitive Information Processing (CIP)}

Pendekatan Cognitive Information Processing (CIP) untuk aplikasi konseling karir membutuhkan pemahaman tentang teori proses informasi kognitif (Tan, 2004). Sampson, Peterson, Reardon, dan Lenz (Atta, dkk, 2013) menjelaskan bahwa pemecahan masalah karir dan pengambilan keputusan karir yang efektif memerlukan pengolahan informasi yang efektif yang mencakup pengetahuan diri, pengetahuan kerja, keterampilan pengambilan keputusan, dan keterampilan pengolahan eksekutif. Pendekatan perkembangan karir dari teori cognitive information processing diilustrasikan menggunakan piramida pemrosesan infromasi dari Robert Stenberg dalam memahami inteligensi manusia (Sharf, 2006). Berikut merupakan gambar domain piramida pemrosesan informasi dalam pengambilan keputusan karir:

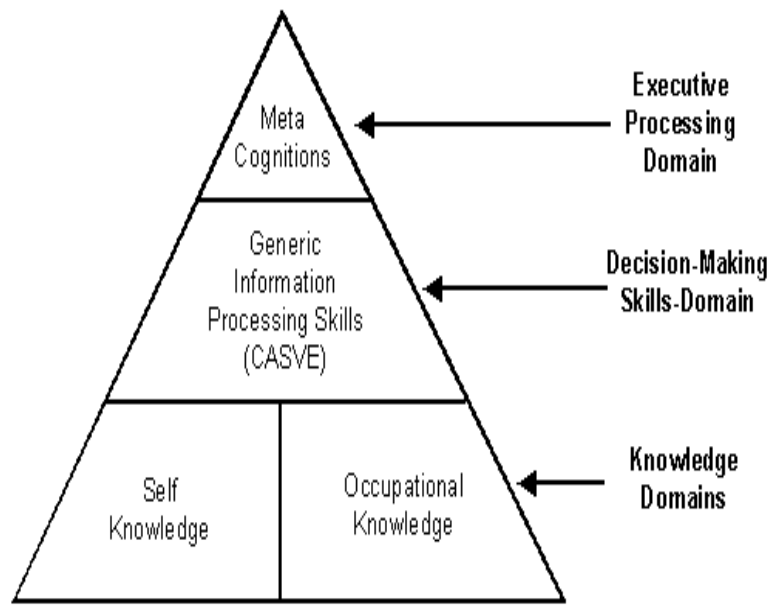

\section{Gambar 2. Pyramid of Information Processing Domains in Career Decision Making}

Peterson, Sampson dan Reardon menjelaskan tentang pendekatan cognitive information processing (CIP) ini didasarkan pada premis bahwa konseling karir harus lebih fokus pada membantu individu mengembangkan kemampuan untuk membuat keputusan karir bijaksana (Hornyak, 2007). Melalui penggunaan piramida pengolahan informasi dan siklus CASVE, konselor dan siswa dapat bekerja sama untuk menerapkan restrukturisasi kognitif (Perry, 2012). Berikut merupakan penjelasannya:

\section{Step 1: Initial Interview}

Pengumpulan informasi tentang konteks permasalahan karir klien. Konselor membangun hubungan dengan klien, menjelaskan domain piramida pengolahan informasi dan siklus CASVE.

2. Step 2: Preliminary assessment
Konselor menilai kesiapan klien untuk penyelesaian masalah dan pengambilan keputusan dan memberikan instrumen untuk melakukan skrining, misalnya menggunakan Career Inventory Thoughts (CTI).

3. Step 3: Define problem and analyze causes

Konselor dan klien mendefinisikan dan mengklarifikasi permasalahan, sehingga klien dapat mengembangkan tujuannya.

4. Step 4: Formulate goals

Konselor dan klien berkolaborasi dalam membangun tujuan klien berdasarkan pemeriksaan masalah karir pada tahap sebelumnya. Tujuan yang dibuat akan menjadi dasar dari individual learning plan di tahap selanjutnya.

5. Step 5: Develop individual learning plan

Konselor membantu klien dalam mengembangkan rencana pembelajaran individual (ILP) yang akan mengidentifikasi sumber daya dan layanan yang diperlukan untuk mencapai tujuan yang tertera pada ILP tersebut.

6. Step 6: Complete the individual learning plan

Dengan bantuan konselor, klien menindaklanjuti rencana pembelajaran individual yang terintegrasi dengan siklus CASVE.

7. Step 7: Summarize review and generalization Setelah klien menyelesaikan ILP, konselor dan klien mengulas dan mendiskusikan kemajuan dari tahap-tahap sebelumnya. Ulasan yang dilakukan fokus pada kemampuan belajar dalam penyelesaian masalah dan kemampuan pengambilan keputusan karir.

\section{HIPOTESIS PENELITIAN}

Hipotesis yang diajukan dala penelitian ini adalah terdapat pengaruh pemberian konseling karir kelompok dengan menggunakan pendekatan cognitive information processing (CIP) terhadap peningkatan kemampuan pengambilan keputusan karir pada siswa SMA.

\section{METODE}

\section{Subjek Penelitian}

Subjek dalam penelitian ini adalah siswa kelas XI SMA yang telah berusia 17 tahun, berjenis berjenis kelamin laki-laki maupun perempuan, serta memiliki tingkat kemampuan pengambilan keputusan karir pada kategori rendah-sedang.

\section{Metode Pengumpulan Data}

Metode pengumpulan data dalam penelitian ini berupa skala yang berisi butir-butir 


\section{Journal of Psychological Science and Profesion (JPSP)}

Vol.2, No.1, April 2018

E-mail: jurnal.psp@unpad.ac.id

pernyataan yang akan dijawab oleh subjek penelitian. Skala yang digunakan dalam penelitian ini adalah career thought inventory

\section{Skala Career Thought Inventory (CTI)}

Skala career thought inventory ini dirancang oleh peneliti berdasarkan konsep career thought inventory dari Peterson, dkk (Sharf, 2006). Koefisien reliabilitas skala CTI ini adalah 0,904 , sedangkan koefisien validitasnya bergerak pada angka 0,308-0,597.

\section{Prosedur Penelitian}

1. Persiapan Penelitian

Peneliti mendapatkan surat izin penelitian dari Fakultas Psikologi dan IImu Sosial Budaya Universitas Islam Indonesia untuk disampaikan kepada pihak terkait.

2. Penyusunan rancangan penelitian dan Pembuatan Pedoman

Intervensi yang digunakan berupa konseling karir kelompok cognitive information processing. Konseling ini bertujuan untuk meningkatkan kemampuan pengambilan keputusan karir siswa yang dilakukan melalui proses pengolahan informasi kognitif yang relevan dengan pilihan karir yang diminati. Pedoman konseling karir kelompok cognitive information processing ini dirancang oleh peneliti berdasarkan seven-step delivery sequnce oleh Peterson, dkk (2006).

3. Penyusunan alat ukur dan uji coba alat ukur

Penelitian ini menggunakan alat ukur berupa skala career thought inventory yang terdiri dari 38 aitem. Setelah diujicobakan kepada 207 siswa SMA kelas XI - XII, jumlah aitem menjadi 20. Penyusunan skala ini dibuat oleh peneliti berdasarkan konsep career thought inventory dari Peterson, dkk (Sharf, 2006).

\section{Metode Analisis Data}

Metode analisis data yang digunakan berupa metode statistik dengan teknik analisis non-parametrik Mann Whitney $U$ Test dengan bantuan program SPSS 17.00 for windows

\section{HASIL DAN PEMBAHASAN}

\section{Deskripsi Data Penelitian}

Data dalam penelitian ini mendeskripsikan 16 subjek penelitian yang terdiri atas 6 subjek kelompok eksperimen dan 8 subjek kelompok kontrol. Kelompok eksperimen terdiri dari 4 orang laki-laki dan 4 orang perempuan, sedangkan kelompok kontrol terdiri dari 5 orang laki-laki dan 3 orang perempuan.
Tabel 2. Deskripsi statistik perbandingan pretest-posttest kelompok eksperimen dan kelompok kontrol.

Descriptive Statistics

\begin{tabular}{lcccc}
\hline & Group & Mean & $\begin{array}{c}\text { Std. } \\
\text { Deviation }\end{array}$ & N \\
\hline Pretest & Eksperimen & 85.00 & 5.928 & 8 \\
& Kontrol & 86.50 & 4.690 & 8 \\
Posttest & Eksperimen & 103.13 & 7.827 & 8 \\
& Kontrol & 82.63 & 4.658 & 8 \\
Followup & Eksperimen & 101.87 & 7.039 & 8 \\
& Kontrol & 82.00 & 3.854 & 8 \\
\hline
\end{tabular}

Tabel di atas menunjukkan bahwa pada saat pelaksanaan prates, pascates, dan tindak lanjut, terdapat perbedaan nilai mean antara kelompok eksperimen dan kelompok kontrol.

\section{Uji Hipotesis}

Uji hipotesis non-parametrik yang akan dilakukan adalah Mann Whitney $U$ Test. Uji nonparametrik ini digunakan dengan pertimbangan jumlah subjek penelitian yang terbatas.

\section{Tabel 3. Hasil Uji Hipotesis}

\begin{tabular}{|c|c|c|c|}
\hline Data & $\mathbf{Z}$ & $\mathbf{P}$ & Keterangan \\
\hline Prates & $-0,526$ & 0,645 & $\begin{array}{c}\text { Tidak } \\
\text { Signifikan }\end{array}$ \\
\hline $\begin{array}{c}\text { Pascates } \\
\text { Pan }\end{array}$ & $\begin{array}{l}-3,313 \\
-3,363\end{array}$ & 0,000 & Signifikan \\
\hline
\end{tabular}

Hasil analisis Mann Whitney yang telah dilakukan pada data prates menunjukkan bahwa nilai $Z=-0,526$ dan $p=0,645(p>0,05)$. Hal ini menunjukkan bahwa tidak ada perbedaan antara kelompok eksperimen dengan kelompok kontrol pada saat pelaksanaan prates. Hasil ini dianggap wajar mengingat kondisi awal subjek pada kedua kelompok memang diharapkan sama atau tidak ada perbedaan. Kemudian hasil analisis yang dilakukan pada data pascates menunjukkan bahwa nilai $Z=-3,313$ dan $p=0,000(p<0,05)$. Hal ini menunjukkan bahwa ada perbedaan pada saat pelaksanaan pascatesantara kelompok eksperimen dengan kelompok kontrol. Kondisi yang sama juga terjadi pada data tindak lanjut, dimana nilai $Z=-3,363$ dan $p=0,000(p<0,05)$. Hal ini menunjukkan bahwa ada perbedaan antara kelompok eksperimen dengan kelompok kontrol pada pelaksanaan tindak lanjut. Maka dapat disimpulkan bahwa hipotesis dalam penelitian ini diterima, yaitu terdapat pengaruh 


\section{Journal of Psychological Science and Profesion (JPSP)}

Vol.2, No.1, April 2018

E-mail: jurnal.psp@unpad.ac.id

konseling karir kelompok cognitive information processing terhadap peningkatkan kemampuan pengambilan keputusan pada siswa.

\section{Pembahasan}

Tujuan dari penelitian ini adalah untuk meningkatkan kemampuan pengambilan keputusan karir siswa di SMAN "X" Yogyakarta melalui konseling karir kelompok cognitive information processing. Hasil penelitian menunjukkan bahwa terdapat perubahan yang signifikan pada skor kemampuan pengambilan keputusan karir pada kelompok eksperimen dan kelompok kontrol. Kelompok eksperimen mengalami perubahan skor yang lebih besar setelah mendapatkan konseling karir kelompok cognitive information processing dibandingkan kelompok kontrol yang tidak mendapatkan konseling karir kelompok cognitive information processing.

Hasil penelitian ini sekaligus memperkuat penelitian sebelumnya terkait intervensi kelompok karir menggunakan pendekatan cognitive information processing. Perry (2012) membuktikan bahwa dampak dari intervensi kelompok karir menggunakan cognitive information processing (CIP) mampu meningkatkan kemampuan pengambilan keputusan karir dan pemecahan masalah pada mahasiswa. Selain itu, hasil penelitian dari Lenz, dkk (2009) menggambarkan bahwa konseling karir menggunakan teori cognitive information processing (CIP) dapat menuntun keputusan tentang mengintegrasikan karir dan kesehatan mental.

Berdasarkan hasil analisis kualitatif wawancara yang dilakukan pada responden, didapatkan data bahwa peserta menjadi lebih yakin dalam melakukan keputusan karir dan kecemasan mereka terkait masa depan menurun seiring dengan keyakinan mereka yang meningkat. Hal tersebut serupa dengan hasil penelitian tesis yang dilakukan oleh Giallombardo (2005) membuktikan bahwa rasa cemas dan gugup dalam mengambil keputusan karir mengalami penurunan pada kelompok yang menerima konseling karir kelompok. Hal tersebut mengindikasikan bahwa konseling karir kelompok membantu siswa untuk memahami nilai-nilai, minat dan bagaiman mereka melakukan keputusan karir.

Menurut Super (Sharf, 2006) siswa SMA termasuk dalam tahap eksplorasi, dimana individu belajar mengenai level pekerjaan yang sesuai dengan diri dan mempelajari skill yang dibutuhkan untuk pekerjaan yang diinginkan. Siswa SMA mulai menyadari kemampuan, ketertarikan dan nilai yang mereka miliki serta mulai berfikir apa yang ingin dilakukannya. Adapun faktor-faktor yang mempengaruhi keputusan karir seseorang adalah faktor internal (nilai-nilai, taraf inteligensi, bakat, minat, sifat-sifat, pengetahuan, dan keadaan jasmani) dan faktor eksternal (masyarakat, keadaan sosial ekonomi negara/ daerah, status sosial ekonomi keluarga, seluruh anggota keluarga besar maupun keluarga inti, pendidikan sekolah, pergaulan teman sebaya, dan tuntutan jabatan/ program studi) (Winkel dan Hastuti, 2006).

Symes (Giallombardo, 2005) menemukan bahwa konseling kelompok karir menyediakan kesempatan bagi individu untuk belajar informasi tentang diri mereka sendiri, memperoleh pengetahuan dan keterampilan tentang proses pengambilan keputusan karir. Berdasarkan hasil analisis kualitatif observasi dan wawancara, didapatkan data bahwa setelah mengikuti konseling karir kelompok, responden menjadi lebih mampu mempertimbangkan faktor internal dan faktor eksternal dengan mengolah informasi yang telah didapatkan dalam proses pengambilan keputusan karirnya. Responden telah melalui proses pemahaman diri, pemahaman terkait karir, serta meningkatkan keterampilan mereka dalam memilah informasi yang mereka miliki sehingga mampu membuat prioritas pilihan.

Melalui proses menganalisa dan mensintesa, responden mampu memformulasikan tujuan dan menyusun langkah-langkah dalam pencapaiannya. Hal tersebut didukung oleh pendapat Sampson, Peterson, Reardon, dan Lenz (Atta, dkk, 2013) bahwa pemecahan masalah karir dan pengambilan keputusan karir yang efektif memerlukan pengolahan informasi yang efektif yang mencakup pengetahuan diri, pengetahuan kerja, keterampilan pengambilan keputusan, dan keterampilan metakognisi.

Pyle (Giallombardo, 2005) mengemukakan bahwa konseling karir kelompok menyediakan sejumlah keuntungan tertentu termasuk biaya dan efektivitas waktu, meningkatkan kesempatan untuk umpan balik pribadi, penurunan rasa isolasi, memfasilitasi pengalaman afektif dan belajar kognitif, serta peningkatan eksplorasi diri.

Berdasarkan hasil analisa kualitatif observasi dan wawancara, didapatkan data bahwa responden menjadi lebih aktif dalam mencari informasi terkait jurusan yang akan mereka pilih setelah lulus, serta mempertimbangkan prospek karirnya. Dari segi afektif, responden merasa memiliki teman dengan permasalahan yang sama dan merasa mendapatkan dukungan. Sedangkan dari segi kognitif belajar, responden merasa terbantu untuk saling bertukar solusi maupun umpan balik melalui proses diskusi / sharing. 


\section{Journal of Psychological Science and Profesion (JPSP)}

Vol.2, No.1, April 2018

E-mail: jurnal.psp@unpad.ac.id

\section{SIMPULAN}

Berdasarkan hasil analisis data dan pembahasan yang telah dilakukan, maka dapat disimpulkan bahwa konseling karir kelompok cognitive information processing berpengaruh terhadap peningkatan kemampuan pengambilan keputusan karir siswa.

\section{SARAN}

1. Bagi Pihak Sekolah, khususnya guru BK hendaknya dapat menerapkan program secara rutin dalam meningkatkan kemampuan pengambilan keputusan karir siswa, seperti diskusi kecil di dalam kelas terkait eksplorasi karir dan eksplorasi diri melalui interaksi kelompok. Selain itu, pihak sekolah dapat menekankan pada setiap guru untuk memberikan informasi karir sesuai dengan mata pelajaran yang diampu pada saat proses mengajar di kelas.

2. Bagi siswa, dapat meningkatkan kemampuan pengambilan keputusan karir dengan melakukan eksplorasi terkait pengetahuan diri dan pengetahuan karir, baik yang memiliki orientasi karir yang menuju perkuliahan maupun pekerjaan. Selain itu, hendaknya siswa mampu menyusun perencanaan untuk mencapai tujuan karir yang diinginkan sejak dini, serta berkomitmen untuk melaksanakannya.

3. Bagi konselor, hasil penelitian ini dapat dijadikan sebagi dasar ilmiah untuk kajian program intervensi dalam meningkatkan kemampuan pengambilan keputusan karir siswa.

4. Bagi peneliti selanjutnya, apabila tertarik dengan penelitian konseling karir kelompok cognitive information processing disarankan untuk meneliti responden yang berbeda dan mengkaji permasalahan pengambilan keputusan karir dengan lebih luas dan mendalam. Selanjutnya, peneliti sebaiknya dapat mengembangkan alat ukur Career Thought Inventory (CTI) versi Indonesia, sehingga dapat digunakan secara luas untuk intervensi karir di banyak instansi. Peneliti hendaknya juga mempertimbangkan lembar kerja yang dapat dikerjakan oleh responden di rumah karena mempengaruhi kualitas tugas yang dikerjakan oleh responden.

\section{DAFTAR PUSTAKA}

Brown, S. D., \& Lent, R. W. (Eds.). (2004). Career development and counseling: Putting theory and research to work. John Wiley \& Sons.

Fasha, F., Sinring, A., \& Aryani, F. (2015). Pengembangan Model E-Career untuk Meningkatkan Keputusan Karir Siswa SMA Negeri 3 Makassar. Jurnal Psikologi Pendidikan \& Konseling, 1(2), 170-179.

Germeijs, V., \& Verschueren, K. (2006). High school students' career decision-making process: Development and validation of the study choice task inventory. Journal of Career Assessment, 14(4), 449-471.

Giallombardo, L. (2005). Using Group Counseling to Implement a Career Development Program with High School Students.

Gushue, G. V., Scanlan, K. R., Pantzer, K. M., \& Clarke, C. P. (2006). The relationship of career decision-making self-efficacy, vocational identity, and career exploration behavior in African American high school students. Journal of Career Development, 33(1), 19-28.

Hastuti, W. (2006). Bimbingan dan Konseling di Institusi Pendidikan.

Hornyak, D. A. (2007). Utilizing cognitive information processing theory to assess the effectiveness of DISCOVER on college students' career development (Doctoral dissertation, University of Pittsburgh).

Lenz, J. G., Peterson, G. W., Reardon, R. C., \& Saunders, D. E. (2010). Connecting career and mental health counseling: Integrating theory and practice. VISTAS 2010.

Myrick, R. D. (1987). Developmental guidance and counseling: A practical approach. Educational Media Corporation, PO Box 21311, Minneapolis, MN 55421.

Perry, A. (2012). The Impact of a Cognitive Information Processing Intervention on Students in First-year Non-career Development College Courses: A Dissertation Submitted to the Graduate School in Candidacy for the Degree of Doctor of Education (Doctoral dissertation, Benedictine University)..

Rowland, K. (2004). Career Decision-Making Skills of High School Students in the Bahamas. Journal of Career Development, 90-100, 31(1).

Sharf, R. S. (2016). Applying career development theory to counseling. Nelson Education.

Steinberg, J. (2009). Cognitive Psychology (5th Ed.). Wadsworth: Cengage Learning.

Tan, E. (2004). Career guidance and career counseling in schools. E. Tan (2004) Counselling in schools. Singapore: McGraw Hill. 
Journal of Psychological Science and Profesion (JPSP)

Vol.2, No.1, April 2018

E-mail: jurnal.psp@unpad.ac.id

Witko, K., Bernes, K. B., Magnusson, K., \& Bardick, A. D. (2009). Senior high school career planning: What students want. The Journal of Educational Enquiry, 6(1). 